Max-Planck-Institut für demografische Forschung Max Planck Institute for Demographic Research Konrad-Zuse-Strasse 1 - D-18057 Rostock · GERMANY

Tel +49 (0) 3812081 - 0; Fax +49 (0) 3812081 - 202;

http://www.demogr.mpg.de

MPIDR WORKING PAPER WP 2004-020

JUNE 2004

Sample size and statistical significance of hazard regression parameters. An exploration by means of Monte Carlo simulation of four transition models based on Hungarian GGS data

Martin Spielauer (spielauer@ demogr.mpg.de)

René Houle (houle@demogr.mpg.de)

This working paper has been approved for release by: Vladimir M. Shkolnikov (shkolnikov@ demogr.mpg.de), Head of the Laboratory for Demographic Data.

(C) Copyright is held by the authors.

Working papers of the Max Planck Institute for Demographic Research receive only limited review. Views or opinions expressed in working papers are attributable to the authors and do not necessarily reflect those of the Institute. 


\title{
Sample size and statistical significance of hazard regression parameters. An exploration by means of Monte Carlo simulation of four transition models based on Hungarian GGS data*
}

\author{
M. Spielauer and R. Houle
}

June 2004

\begin{abstract}
In this paper, we explore the relation between sample sizes of female respondents aged 1844 and the statistical significance of parameter estimates in four piecewise constant proportional hazard regression models by means of microsimulation. The underlying models for first marriage, first birth, second birth, and first divorce are estimated from Hungarian GGS data and interpreted and used as typical event-history models for the analysis of GGS data in general.

The models are estimated from the full biographies as well as from three- and six-year inter-panel biographies of the simulated samples.

The simulation results indicate that there is great sensibility of the parameters that reach statistical significance to the sample size precisely in the sample range of the GGS. This means that any reduction or increase in the sample size will notably affect the statistical analysis of the data. Marginal gains in terms of the number of significant parameters are especially high up to 3.000 respondents when applying rather modest thresholds of significance. For higher thresholds, marginal gains remain steep for sample sizes up to 5.000 respondents. When analyzing inter-panel histories, especially for a single three-year interval, the likelihood that parameter estimates are significant is very moderate. For 6-year inter-panel histories, we get better results, at least for a sample size of at least 3.000. When reducing the sample size to below 3.000, the number of significant results for inter-panel histories deteriorates rapidly.
\end{abstract}

\footnotetext{
* The original idea of this work stems from Jan Hoem. We would like to thank him as well as Andres Vikat and Vladimir Shkolnikov for useful comments on earlier versions of this paper. We are grateful to Zsolt Spéder for making available the First Wave Hungarian GGS data set for this experiment. Rainer Walke also has made a very valuable contribution with Stata programming, which saved us a great deal of repetitive work.
} 


\section{Introduction}

The objective of this study is to simulate four demographic transitions to assess the effects of a GGS sample size on the statistical significance of hazard regression parameters in three situations, namely for full histories and for three- and six year inter-panel biographies. A three-year panel period corresponds to the realization of two waves, and a six-year period to three waves. In the GGS, panel waves are three years apart from one another.

The transitions are first marriage, first and second birth, and divorce from first marriage of the female population aged 18-44. Since Hungary has just made available the data set of its first GGS wave (the Hungarian Social and Demographic Panel Survey), it is a good opportunity for our test to be as realistic as possible. The first wave of the survey, an initiative of the Demographic Research Institute of the Hungarian Central Statistical Office, took place in 2001 among 7.747 men and 8.616 women aged between 18 and 75. It covers topics such as marriage formation and dissolution, cohabitation, fertility, retirement, living conditions of pensioners. and relations between generations and genders. A more detailed presentation of the survey is found in Spéder (2001).

\section{The models and variables}

We use four different demographic transitions that pertain to family behavior and that are considered classic, or basic, ones. They cover a good range of the family life-cycle during its reproductive years. Process time and female population at risk for each one are presented in Table 1.

\begin{tabular}{|c|c|c|}
\hline Transition & $\begin{array}{c}\text { Process time } \\
\text { (months) }\end{array}$ & Population at risk \\
\hline First marriage & Age & Never married \\
\hline First birth & Age & Childless \\
\hline Second birth & Time since first birth & With one child \\
\hline $\begin{array}{c}\text { Marital separation from } \\
\text { first marriage }\end{array}$ & Marriage duration & In first marriage \\
\hline
\end{tabular}

Table 1: Process time and population at risk

We first estimated four hazard models (one for each transition) from the original Hungarian data with all of the 4.289 women aged 18-44 (women in reproductive age). Piecewise exponential regression from STATA was used for modeling. The general model takes the form

$$
\ln h_{i}(t)=y(t)+\sum_{k} \beta_{k} u_{i k}(t)+\sum_{k^{\prime}} \alpha_{k^{\prime}} x_{i k^{\prime}}
$$


where $\ln h_{i}(t)$ represents the natural logarithm of the hazard rate for any of our four transitions, $\mathrm{y}(\mathrm{t})$ is the piecewise constant hazard baseline, $\sum_{k} \beta_{k} u_{i k}(t)$ the effects of timevarying covariates (e.g. the number of children) and $\sum_{k^{\prime}} \alpha_{k^{\prime}} x_{i k^{\prime}}$ the effects of time-constant covariates (in our case, taken at the time of the survey).

The list of covariates for each transition is displayed in Table 2.

\begin{tabular}{|c|c|c|c|}
\hline First marriage & First birth & Second birth & Divorce \\
\hline $\begin{array}{ll}\text { - } & \text { Cohort (age at } \\
\text { - } & \text { Eurvey) } \\
& \text { aducation } \\
\text { - } & \text { Religiosity } \\
\text { - } & \text { Residence } \\
\text { - } & \text { Number of } \\
\text { children born }\end{array}$ & $\begin{array}{ll}\text { - } & \text { Cohort (age at } \\
\text { - } & \text { Edurvey) } \\
\text { - } & \text { attainmention } \\
\text { - } & \text { Religiosity } \\
\text { - } & \text { Residence } \\
\text { - } & \text { Marital status }\end{array}$ & $\begin{array}{ll}\text { - } & \text { Cohort (age at } \\
& \text { survey) } \\
\text { - } & \text { Education } \\
& \text { attainment } \\
\text { - } & \text { Religiosity } \\
\text { - } & \text { Residence } \\
\text { - } & \text { Marital status }\end{array}$ & $\begin{array}{ll}\text { - } & \text { Cohort (age at } \\
\text { - } & \text { Edurvey) } \\
\text { attainmention } \\
\text { - } & \text { Religiosity } \\
\text { - } & \text { Residence } \\
\text { - } & \text { Number of } \\
\text { children born }\end{array}$ \\
\hline
\end{tabular}

Table 2: Covariates used in modeling

The Hungarian GGS contains partnerships and birth histories but, unfortunately, the first wave does not include education or employment histories. This not only limits the use of time-varying covariates, but also the number of covariates available for the simulation. Many variables were actually available, but most of them proved to be too endogenous. This applies to income variables, for example.

The number of covariates was thus kept small. We aimed at having some significant covariates in the models that could account in some way for behavioral patterns in all four transitions. The choice remains obviously very subjective, and possibly benefits from improvement. The categories of these covariates are defined in Table 3 (ref indicates the reference category in the models) and categories for baselines in Table 4.

The four models include the same fixed covariates. However, the time-varying covariates for the two marriage processes (marriage and divorce) differ from the two birth processes (first and second birth). In the marriage processes, number of children is the time-varying covariate, whereas in the birth processes, the time-varying covariate is marital status. By doing this, we make the system complete, and this improves simulation input (see below). This means that we can calculate on a monthly basis the risks of marriage and divorce according to the number of children at any time and the risks of first and second birth according to the marital status at any time. 


\begin{tabular}{|c|c|}
\hline Covariates & Transitions \\
\hline $\begin{array}{l}\text { Cohort (age at survey) } \\
\text { - } \quad 18-24 \text { year olds } \\
\text { - } 25-34 \text { year olds } \\
\text { - } \quad 35-44 \text { year olds (ref) }\end{array}$ & All \\
\hline $\begin{array}{l}\text { Education attainment } \\
\text { - } \quad \text { Primary or less } \\
\text { - Secondary completed (ref) } \\
\text { - } \quad \text { Post-secondary and higher }\end{array}$ & All \\
\hline $\begin{array}{l}\text { Religiosity } \\
\text { - } \quad \text { Not religious (ref) } \\
\text { - } \quad \text { Religious in some way }\end{array}$ & All \\
\hline $\begin{array}{l}\text { Residence } \\
\text { - } \quad \text { Living outside Budapest (ref) } \\
\text { - } \quad \text { Living in Budapest }\end{array}$ & All \\
\hline $\begin{array}{l}\text { Number of children born (time-varying) } \\
\text { - } \quad \text { No children (ref) } \\
\text { - } 1 \text { child } \\
\text { - } 2 \text { children + }\end{array}$ & $\begin{array}{l}\text { Marriage } \\
\text { Divorce }\end{array}$ \\
\hline $\begin{array}{l}\text { Marital status (time-varying) } \\
\text { - Never married } \\
\text { - At least married once and never divorced/separated (ref) } \\
\text { - } \quad \text { Ever divorced/separated }\end{array}$ & $\begin{array}{l}\text { First birth } \\
\text { Second birth }\end{array}$ \\
\hline
\end{tabular}

Table 3: Categories of covariates

\begin{tabular}{|c|c|c|c|}
\hline $\begin{array}{c}\text { First marriage } \\
\text { (age) }\end{array}$ & $\begin{array}{c}\text { First birth } \\
\text { (age) }\end{array}$ & $\begin{array}{c}\text { Second birth } \\
\text { (years since first } \\
\text { birth) }\end{array}$ & $\begin{array}{c}\text { Divorce } \\
\text { (marriage } \\
\text { duration in years) }\end{array}$ \\
\hline $15-16$ & $15-16$ & 0 & 0 \\
$17-19$ & $17-19$ & $1-4$ & 1 \\
$20-24$ & $20-24$ & $5-9$ & 2 \\
$25-29$ & $25-29$ & $10-14$ & 3 \\
$30-34$ & $30-34$ & $15-19$ & 4 \\
$35-39$ & $35-39$ & $20-29$ & $5-9$ \\
$40-44$ & $40-44$ & & $10-14$ \\
& & & $15-19$ \\
& & & $20-29$ \\
\hline
\end{tabular}

Table 4: Categories of baselines 


\section{Regression results}

Figure 1 shows the results of hazard baseline estimates in the four models. Baselines are expressed in monthly rates. The baselines give the rates for the combination of covariates at their reference level. With first marriage transition, for instance, the baseline holds for 35-44 year old women covered by the survey, who have completed secondary school, are not religious and living outside Budapest, and during childlessness. Rates for any other group can be calculated by multiplying these rates with the adequate relative risks. The inputs of the simulations are the result of these operations for all possible combinations of covariates (rates are thus proportional to the baselines for any combination of covariates).

Tables $5 \mathrm{a}$ and $5 \mathrm{~b}$ provide regression results for all covariates and their values for the four models. Most coefficients of marriage and first birth models are statistically significant at level 0.05. Naturally, by definition all women are at risk of marrying or having a first child at the beginning of the observation period. Divorce and second birth transition models do not yield similar "positive" results, and in this case not all women are at least once at risk of experiencing these transitions.

Generally, we can say that most, if not all, coefficients have the "right" signs. The effect of time (cohort) and of living in Budapest reduces marriage and fertility but increases divorce risks. Having a higher education level not only reduces marriage and fertility, but also divorce rates as is the case in other industrialized countries (for instance, Sweden and the US). Religiosity does not have a very strong effect on family behaviors, but it may not be very reliable as it may change during the life-cycle. Finally, time-varying covariates are significant, which shows that there is a clear interrelationship between the different family life-course transitions.

These results thus provide the inputs for the simulations. Baselines give the time (or calendar) structure of the occurrences of the four family transitions, while the relative risks determine their exact level for all population groups taken into account in this experiment. 

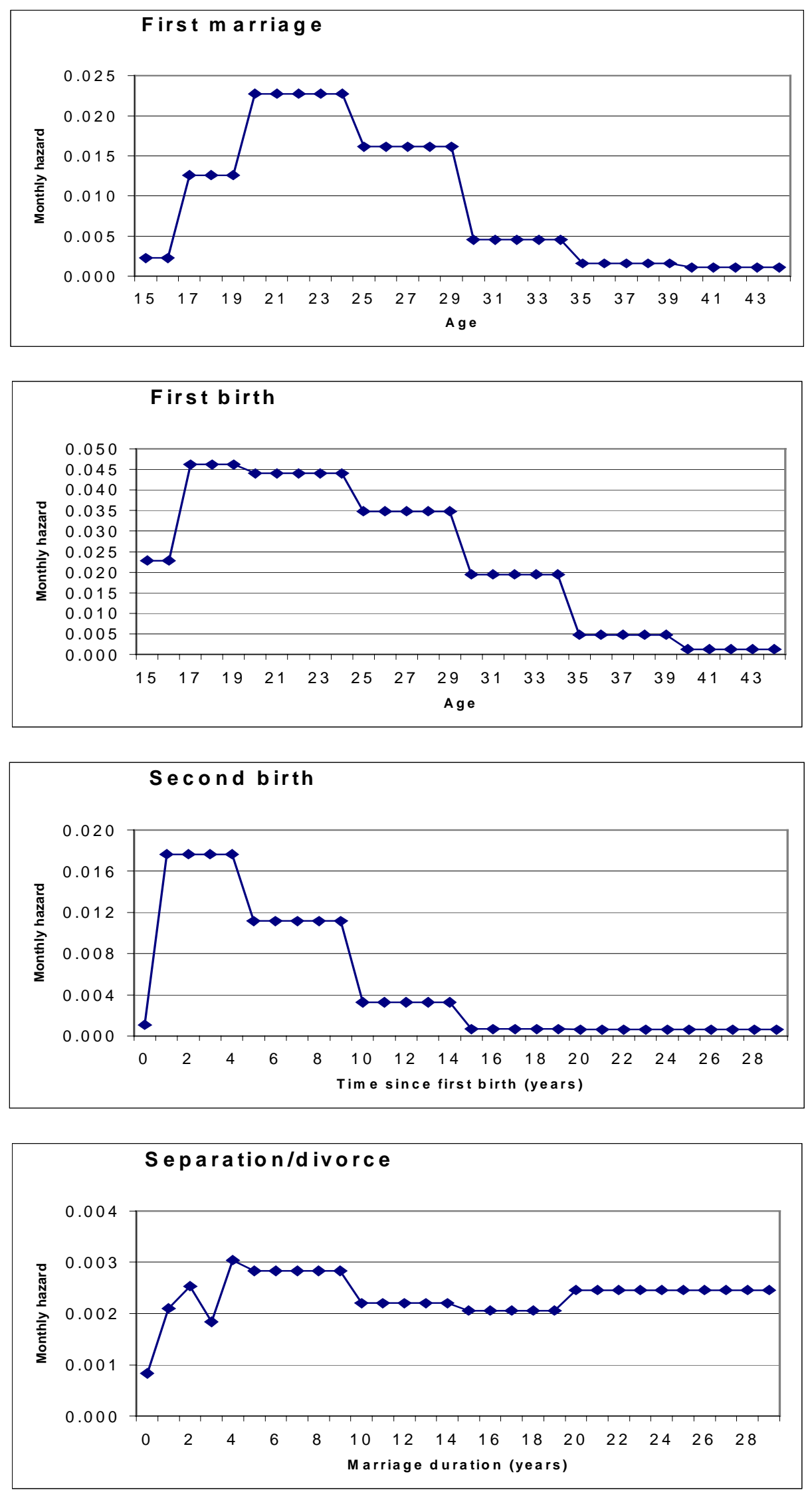

Figure 1: Baseline results for the four models. 


\begin{tabular}{|c|c|c|c|c|}
\hline$\overline{\text { Transition }}$ & Variable & Category & Relative risk & p-value \\
\hline \multirow[t]{6}{*}{ Marriage } & $\begin{array}{l}\text { Cohort } \\
\text { (age at survey) }\end{array}$ & $\begin{array}{l}18-24 \\
25-34 \\
35-44\end{array}$ & $\begin{array}{c}0.19 \\
0.54 \\
1\end{array}$ & $\begin{array}{l}0.000 \\
0.000\end{array}$ \\
\hline & $\begin{array}{l}\text { Education } \\
\text { attainment }\end{array}$ & $\begin{array}{l}\text { Primary } \\
\text { Secondary } \\
\text { Post-secondary }\end{array}$ & $\begin{array}{c}1.30 \\
1 \\
0.59\end{array}$ & $\begin{array}{l}0.000 \\
0.000\end{array}$ \\
\hline & Residence & $\begin{array}{l}\text { Outside Budapest } \\
\text { In Budapest }\end{array}$ & $\begin{array}{c}1 \\
0.64\end{array}$ & 0.000 \\
\hline & Religion & $\begin{array}{l}\text { Not religious } \\
\text { Religious }\end{array}$ & $\begin{array}{c}1 \\
1.17\end{array}$ & 0.000 \\
\hline & $\begin{array}{l}\text { Numb. of } \\
\text { children }\end{array}$ & $\begin{array}{l}\text { No children } \\
1 \text { child } \\
2+\text { children }\end{array}$ & $\begin{array}{c}1 \\
0.73 \\
0.54\end{array}$ & $\begin{array}{l}0.000 \\
0.000\end{array}$ \\
\hline & $\begin{array}{l}\text { Women at risk } \\
\text { Marriages }\end{array}$ & $\begin{array}{l}4289 \\
2642\end{array}$ & & \\
\hline \multirow[t]{6}{*}{ First birth } & $\begin{array}{l}\text { Cohort } \\
\text { (age at survey) }\end{array}$ & $\begin{array}{l}18-24 \\
25-34 \\
35-44\end{array}$ & $\begin{array}{c}0.72 \\
0.84 \\
1\end{array}$ & $\begin{array}{l}0.000 \\
0.000\end{array}$ \\
\hline & $\begin{array}{l}\text { Education } \\
\text { attainment }\end{array}$ & $\begin{array}{l}\text { Primary } \\
\text { Secondary } \\
\text { Post-secondary }\end{array}$ & $\begin{array}{c}1.44 \\
1 \\
0.80\end{array}$ & $\begin{array}{l}0.000 \\
0.000\end{array}$ \\
\hline & Residence & $\begin{array}{l}\text { Outside Budapest } \\
\text { In Budapest }\end{array}$ & $\begin{array}{c}1 \\
0.86\end{array}$ & 0.010 \\
\hline & Religion & $\begin{array}{l}\text { Not religious } \\
\text { Religious }\end{array}$ & $\begin{array}{c}1 \\
0.95\end{array}$ & 0.236 \\
\hline & $\begin{array}{l}\text { Marital } \\
\text { status }\end{array}$ & $\begin{array}{l}\text { Never married } \\
\text { Currently married } \\
\text { Ever divorced }\end{array}$ & $\begin{array}{c}0.04 \\
1 \\
0.39\end{array}$ & $\begin{array}{l}0.000 \\
0.000\end{array}$ \\
\hline & $\begin{array}{l}\text { Women at risk } \\
\text { First births }\end{array}$ & $\begin{array}{l}4289 \\
2548\end{array}$ & & \\
\hline
\end{tabular}

Table 5a: Covariate results for the four models (marriage and first birth). 


\begin{tabular}{|c|c|c|c|c|}
\hline Transition & Variable & Category & Relative risk & p-value \\
\hline \multirow[t]{6}{*}{ Second birth } & $\begin{array}{l}\text { Cohort } \\
\text { (age at survey) }\end{array}$ & $\begin{array}{l}18-24 \\
25-34 \\
35-44\end{array}$ & $\begin{array}{c}1.11 \\
0.93 \\
1\end{array}$ & $\begin{array}{l}0.471 \\
0.181\end{array}$ \\
\hline & $\begin{array}{l}\text { Education } \\
\text { attainment }\end{array}$ & $\begin{array}{l}\text { Primary } \\
\text { Secondary } \\
\text { Post-secondary }\end{array}$ & $\begin{array}{c}1.36 \\
1 \\
1.04\end{array}$ & $\begin{array}{l}\mathbf{0 . 0 0 0} \\
0.528\end{array}$ \\
\hline & Residence & $\begin{array}{l}\text { Outside Budapest } \\
\text { In Budapest }\end{array}$ & $\begin{array}{c}1 \\
0.79\end{array}$ & 0.003 \\
\hline & Religion & $\begin{array}{l}\text { Not religious } \\
\text { Religious }\end{array}$ & $\begin{array}{c}1 \\
1.01\end{array}$ & 0.808 \\
\hline & $\begin{array}{l}\text { Marital } \\
\text { status }\end{array}$ & $\begin{array}{l}\text { Never married } \\
\text { Currently married } \\
\text { Ever divorced }\end{array}$ & $\begin{array}{c}0.50 \\
1 \\
0.58\end{array}$ & $\begin{array}{l}0.000 \\
0.000\end{array}$ \\
\hline & $\begin{array}{l}\text { Women at risk } \\
\text { Second births }\end{array}$ & $\begin{array}{l}2532 \\
1671\end{array}$ & & \\
\hline \multirow[t]{6}{*}{ Divorce } & $\begin{array}{l}\text { Cohort } \\
\text { (age at survey) }\end{array}$ & $\begin{array}{l}18-24 \\
25-34 \\
35-44\end{array}$ & $\begin{array}{c}1.72 \\
1.55 \\
1\end{array}$ & $\begin{array}{l}0.066 \\
\mathbf{0 . 0 0 0}\end{array}$ \\
\hline & $\begin{array}{l}\text { Education } \\
\text { attainment }\end{array}$ & $\begin{array}{l}\text { Primary } \\
\text { Secondary } \\
\text { Post-secondary }\end{array}$ & $\begin{array}{c}1.13 \\
1 \\
0.86\end{array}$ & $\begin{array}{l}0.293 \\
0.219\end{array}$ \\
\hline & Residence & $\begin{array}{l}\text { Outside Budapest } \\
\text { In Budapest }\end{array}$ & $\begin{array}{c}1 \\
1.56\end{array}$ & 0.000 \\
\hline & Religion & $\begin{array}{l}\text { Not religious } \\
\text { Religious }\end{array}$ & $\begin{array}{c}1 \\
0.79\end{array}$ & 0.015 \\
\hline & $\begin{array}{l}\text { Numb. of } \\
\text { children }\end{array}$ & $\begin{array}{l}\text { No children } \\
1 \text { child } \\
2+\text { children }\end{array}$ & $\begin{array}{c}1 \\
0.58 \\
0.34\end{array}$ & $\begin{array}{l}0.000 \\
0.000\end{array}$ \\
\hline & $\begin{array}{l}\text { Women at risk } \\
\text { Divorces }\end{array}$ & $\begin{array}{c}2633 \\
462\end{array}$ & & \\
\hline
\end{tabular}

Table 5b: Covariate results for the four models (second birth and divorce). 


\section{Micro-simulation of synthetic samples}

In order to study the effect of different sample sizes on the significance of model parameters, we produce synthetic samples in which individual biographies follow the probability patterns calculated from the four hazard models described above. These parameters are assumed to represent the "true" behaviors. The distribution of parameter estimates and their significance are then assessed by estimating the same models from 30 simulated samples for each sample size ranging from 1.000 to 16.000 women of reproductive age.

For the simulation of synthetic samples, we synthesize the four behavioral models into a simple dynamic competing risk microsimulation model with a pseudo-continuous time frame of monthly units. The microsimulation model is then applied to produce the different random samples in a series of retrospective projections of the current population ${ }^{1}$.

The production of synthetic samples follows two main steps. We first generate a population that resembles the probability distribution of the time-constant model variables as found in the underlying Hungarian Survey. In the second step, we simulate for each person individual life-course trajectories from age 15 up to the current age, thereby imputing dates of four possible life-course events, namely marriage, first birth, second birth, and divorce. Each occurrence of one of the modeled events changes the time-variant variables and the proceeding events are subsequently simulated using the changed set of individual characteristics.

The timing of these events is determined by the Monte-Carlo simulation based on the four hazard models. Starting from age 15, we determine the occurrence and timing of each possible event, using a monthly time frame. If events occur before the current age of the person in question, the first event (if more than one applies) censors all other processes. After updating all time-variant variables - i.e. parity, civil status and age - and storing the event, the procedure is repeated, starting from this month until the current age of the person is reached.

The simulation algorithm can be described best as Monte-Carlo draws from an underlying survival curve. At age 15, we need to consider two competing events, namely marriage and first birth. Based on the survival curves for the given set of individual characteristics, we determine the occurrence of each of the two events by drawing random numbers between 0

\footnotetext{
1 Microsimulation methods for population projections are described in Imhoff and Post (1998). For a comparison of discrete-time and continuous-time approaches to dynamic microsimulation, see Galler (1997). Further modeling approaches and classifications of models as well as surveys of existing microsimulation models are found in Klevmarken (1997), Merz (1991) and Spielauer (2003).
} 
and 1 and by calculating the corresponding times of events, as illustrated in the following graph.

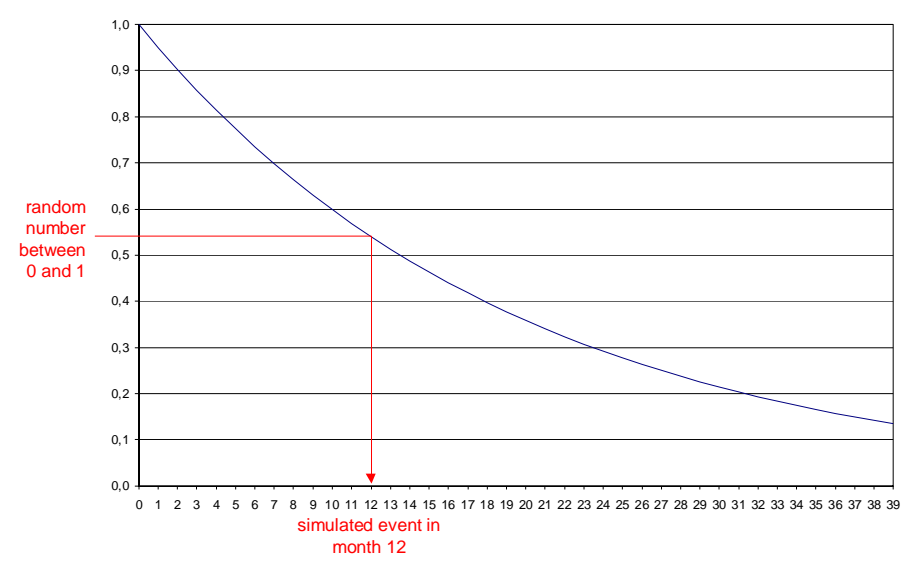

Figure 2: Random draw and corresponding time of event.

The first round of our random experiments has four possible outcomes:

1. No event takes place between the process start at 15 and the current age, and we can accordingly stop the simulation for this person.

2. Marriage occurs as only event or before first birth. We then record the marriage event, update the variables and re-start the process at the month of marriage.

3. Vice versa for first birth being the first event.

4. Both events occur in the same month. Using a monthly time framework, this is very unlikely, but we consider their occurrence nevertheless and proceed accordingly by storing both events and restarting the process at this point in time.

In the second round, we start from the time of the first event, simulating the timing of the next possible events. For instance, after the event of marriage, we need to consider the two competing events divorce and first birth. This procedure is repeated until the current age of the person is reached.

In order to study the effect of the sample size on the distribution and significance level of parameter estimates, the four models are estimated again from the various synthetic samples. From the results of 30 simulation experiments, we extract stepwise 9 samples respectively: $16.000,10.000,6.000,5.000,4.000,3.000,2000,1500$ and 1.000 of age range 18 to 44 . Thereby we obtain 270 samples on which we estimate the same four hazard models. In two following steps, we only include in our analysis the last three and then the last six years of individual biographies, which corresponds to the three and $3+3$ year interpanel intervals.

For the two inter-panel analyses of the three- and six-year interval, the same four models are estimated and we applied the same procedure as above to generate once again 270 
synthetic samples in each case. However, we needed to recreate these two situations from a unique set of data and specify the models to adapt the three-year and six-year "period" situations. The re-creation of a panel perspective meant that we entered women in the equations not from the starting point of the original model described above, but from a point in time three and six years respectively before the end of observation for each woman (which is given by her age at survey). Let us recall that we initially selected women aged 18-44. Therefore, women are aged 18-41 and 21-44 at the first and second wave, respectively. Similarly, women are aged 18-38, 21-41 and 24-44 at the first, second and third wave respectively for the six-year period. We lost some information since the GGS sample comprises a population of 18-79 year olds. Our results for the models apply to panel-like situations and thus give over-estimates of the parameters' values (because the population is not much younger than that of the GGS) and under-estimate their p-values (because there are fewer cases).

The number of women at risk and the number of events from the four base models calculated from the original GGS Hungarian data for each transition in the two panel-like situations and the full histories data set are displayed in Table 6.

\begin{tabular}{|c|c|c|c|c|c|c|}
\hline & \multicolumn{3}{|c|}{ Number of women at risk } & \multicolumn{2}{|c|}{ Number of events } & \multirow[b]{2}{*}{$\begin{array}{c}\text { Full } \\
\text { histories }\end{array}$} \\
\hline & $\begin{array}{l}3 \text {-year } \\
\text { period }\end{array}$ & $\begin{array}{l}\text { 6-year } \\
\text { period }\end{array}$ & $\begin{array}{c}\text { Full } \\
\text { histories }\end{array}$ & $\begin{array}{l}3 \text {-year } \\
\text { period }\end{array}$ & $\begin{array}{l}\text { 6-year } \\
\text { period }\end{array}$ & \\
\hline Marriage & 1881 & 2184 & 4289 & 234 & 537 & 2642 \\
\hline First birth & 1522 & 1827 & 4289 & 253 & 558 & 2548 \\
\hline Second birth & 1053 & 1274 & 2532 & 213 & 434 & 1671 \\
\hline Divorce & 2253 & 2346 & 2633 & 99 & 192 & 462 \\
\hline
\end{tabular}

Table 6: Number of women at risk and number of events in the two panel-like situations, and the full histories data set.

There is a substantive difference between the inter-panel situations and the situations in which we have full histories, and this explains the differences in results, especially in the number of statistically significant estimates, as we will see below.

Some amendments in the specification of the models were also necessary to adapt to the two inter-panel situations. First, we dropped the cohort covariate to prevent the possibility of a strong correlation between this covariate and the baseline. Second, we modified the four baselines due to the small number of events (marriages, first and second births) at older ages. These amendments naturally do not affect the basic results. 


\section{Simulation results for full histories}

An increase of sample size narrows the variance of parameter estimates and therefore their statistical significance becomes greater. The following graphical analysis investigates the distribution of parameter estimates obtained from 30 simulated samples for 7 different sample sizes and determines the significance probability of a given parameter in a sample of a given size. The analysis uses the moderate significance level of $p=0,1$ as we are interested in lower limits of sample sizes. The effect of higher significance levels on required sample sizes is studied separately at the end of this chapter.

In order to assess the probability to obtain "acceptable" parameter estimates for a given sample size, we distinguish four possible estimation results: (1) the parameter is significant and "right" - i.e. greater than unity for over-proportional risks and less than unity for under-proportional risks; (2) the parameter is "right" but not significant; (3) the parameter is "wrong" but not significant; and the worst case: (4) the parameter is "wrong" and significant.

There follow graphs to illustrate the estimation results for the relative risks of the four models. Each figure displays the distribution of the parameters estimated from 30 simulated samples (minimum, maximum, mean and 5\%/95\% percentiles) and indicates the probabilities that an estimated parameter belongs to one of the four groups as described above. For example, first marriage risks are $20 \%$ higher for religious women. If we aim at reaching significant parameter estimates at level 0,1 in $90 \%$ of the samples, we need a sample size of 3.000. With a sample size of 1.000 , we obtain a "wrong" parameter in 3,3\% ( 1 of 30 ) of samples, indicating an under-proportional marriage risk for religious women.

Marginal gains in terms of an increasing probability to obtain significant parameter estimates are very high in the sample range of the GGS. For first marriages, all parameters have at least a $90 \%$ probability to be significant in samples of 3.000. When reducing the sample size to $2.000,2$ of the 8 parameters do not reach this probability threshold. A very steep increase in probabilities to obtain significant estimation results is found for many parameters in all four models. 
MARRIAGE: PARAMETER ESTIMATES FROM 30 SIMULATED SAMPLES FOR DIFFERENT SAMPLE SIZES AND PERCENTAGE OF SAMPLES IN WHICH PARAMETERS ARE SIGNIFICANT AT LEVEL 0,1 - FULL PERIOD

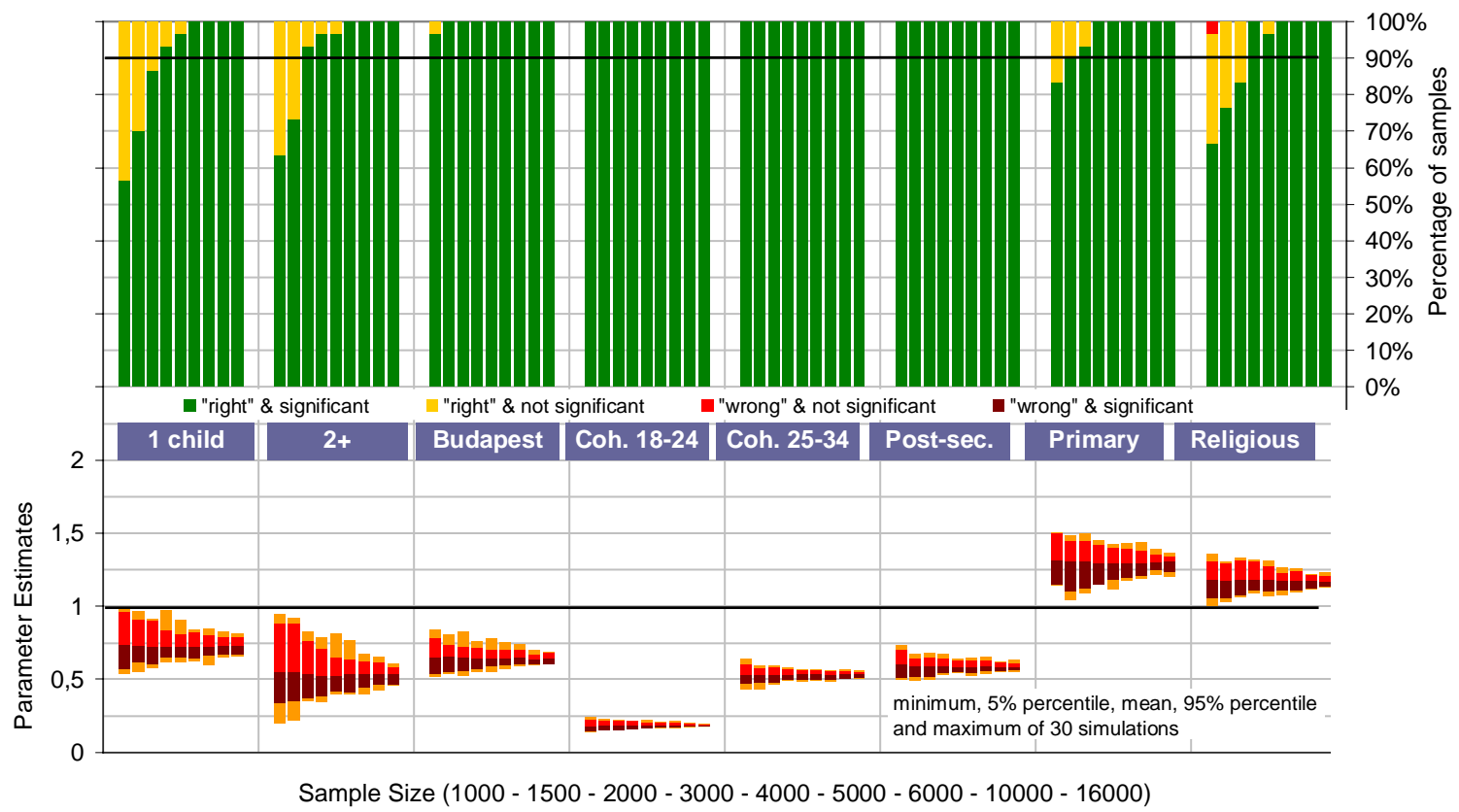

Figure 3: Relative risks of first marriage estimated from full biographies

FIRST BIRTH: PARAMETER ESTIMATES FROM 30 SIMULATED SAMPLES FOR DIFFERENT SAMPLE SIZES AND PERCENTAGE OF SAMPLES IN WHICH PARAMETERS ARE SIGNIFICANT AT LEVEL 0,1 - FULL PERIOD

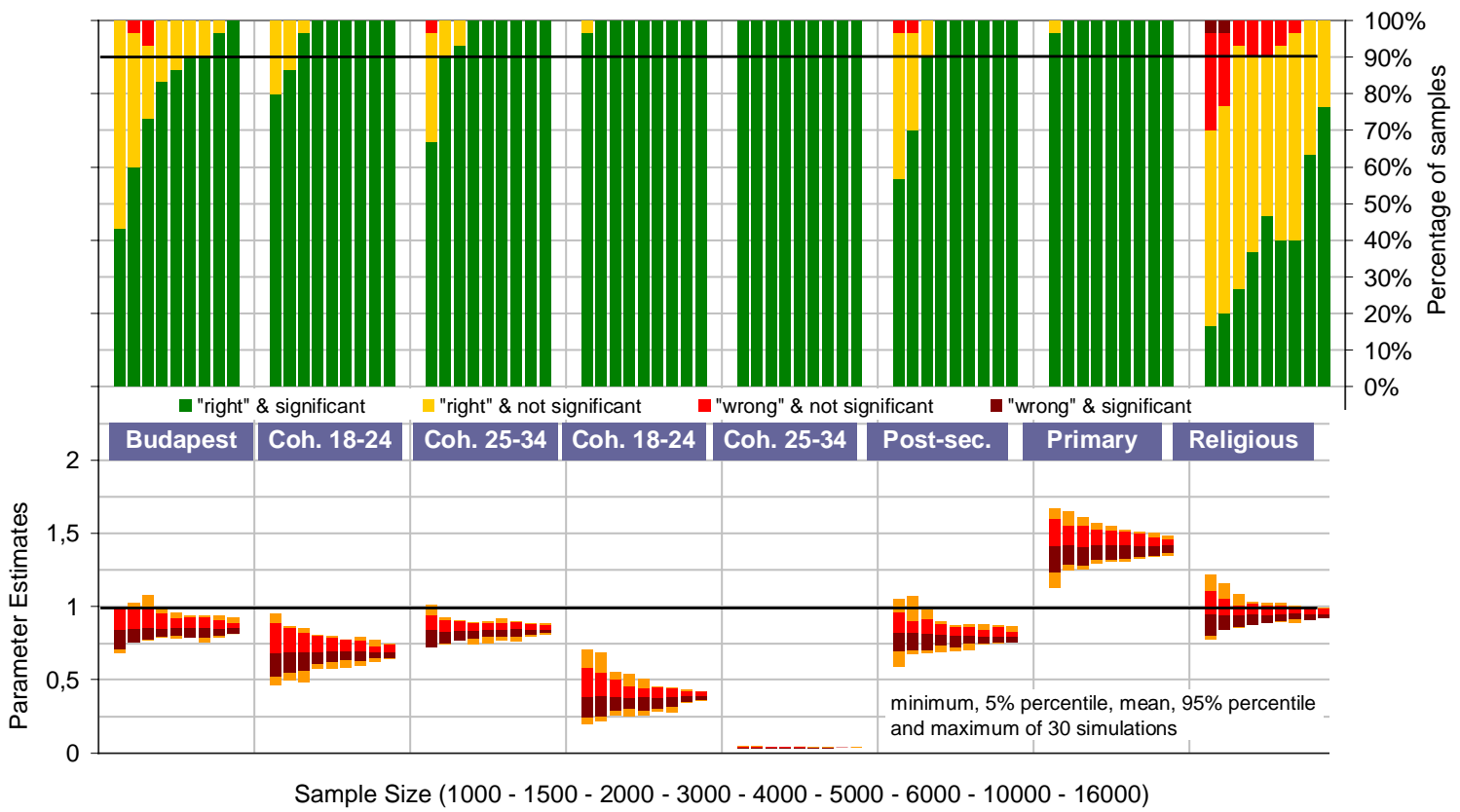

Figure 4: Relative risks of first birth estimated from full biographies 
SECOND BIRTH: PARAMETER ESTIMATES FROM 30 SIMULATED SAMPLES FOR DIFFERENT SAMPLE SIZES AND PERCENTAGE OF SAMPLES IN WHICH PARAMETERS ARE SIGNIFICANT AT LEVEL 0,1 - FULL PERIOD

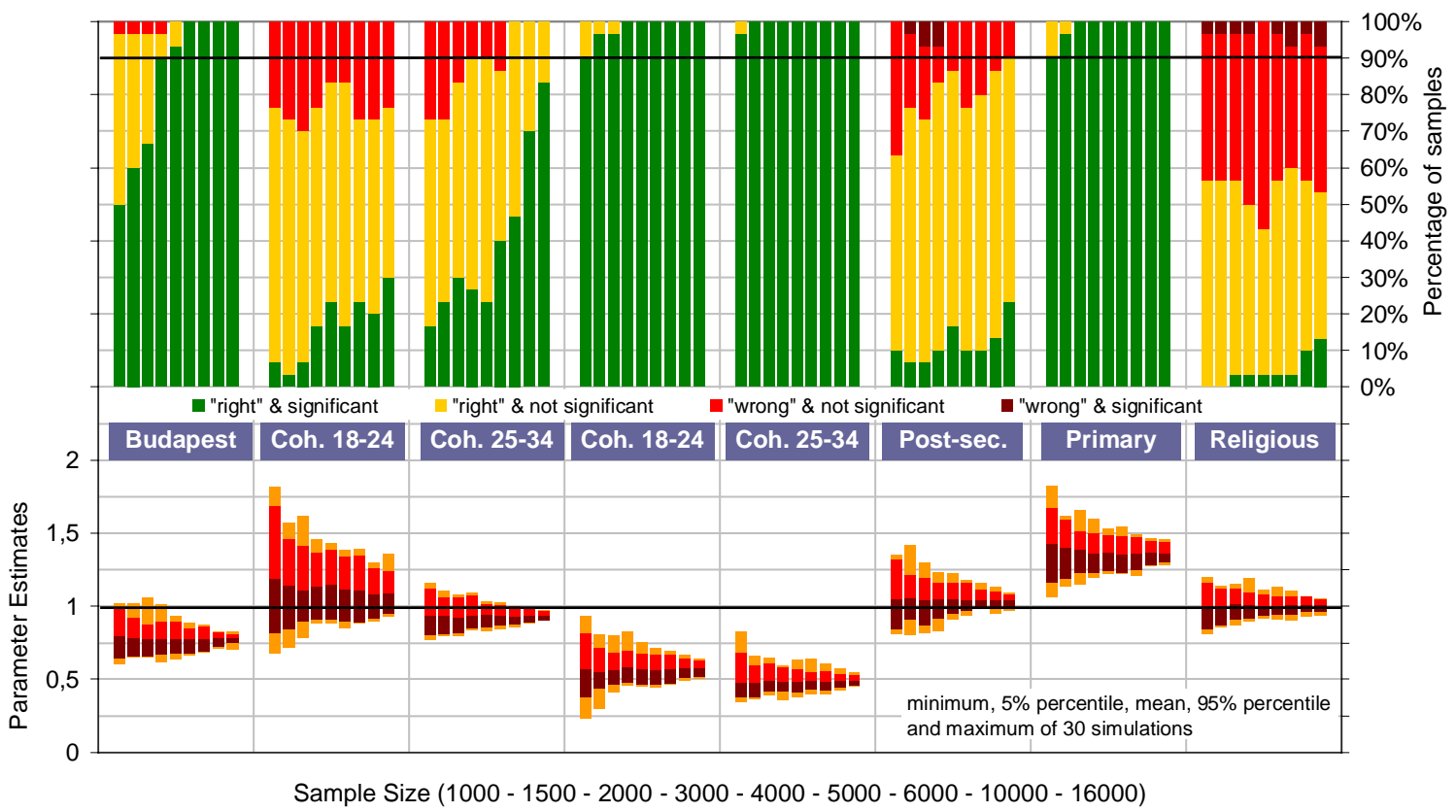

Figure 5: Relative risks of second birth estimated from full biographies

DIVORCE: PARAMETER ESTIMATES FROM 30 SIMULATED SAMPLES FOR DIFFERENT SAMPLE SIZES AND PERCENTAGE OF SAMPLES IN WHICH PARAMETERS ARE SIGNIFICANT AT LEVEL 0,1 - FULL PERIOD

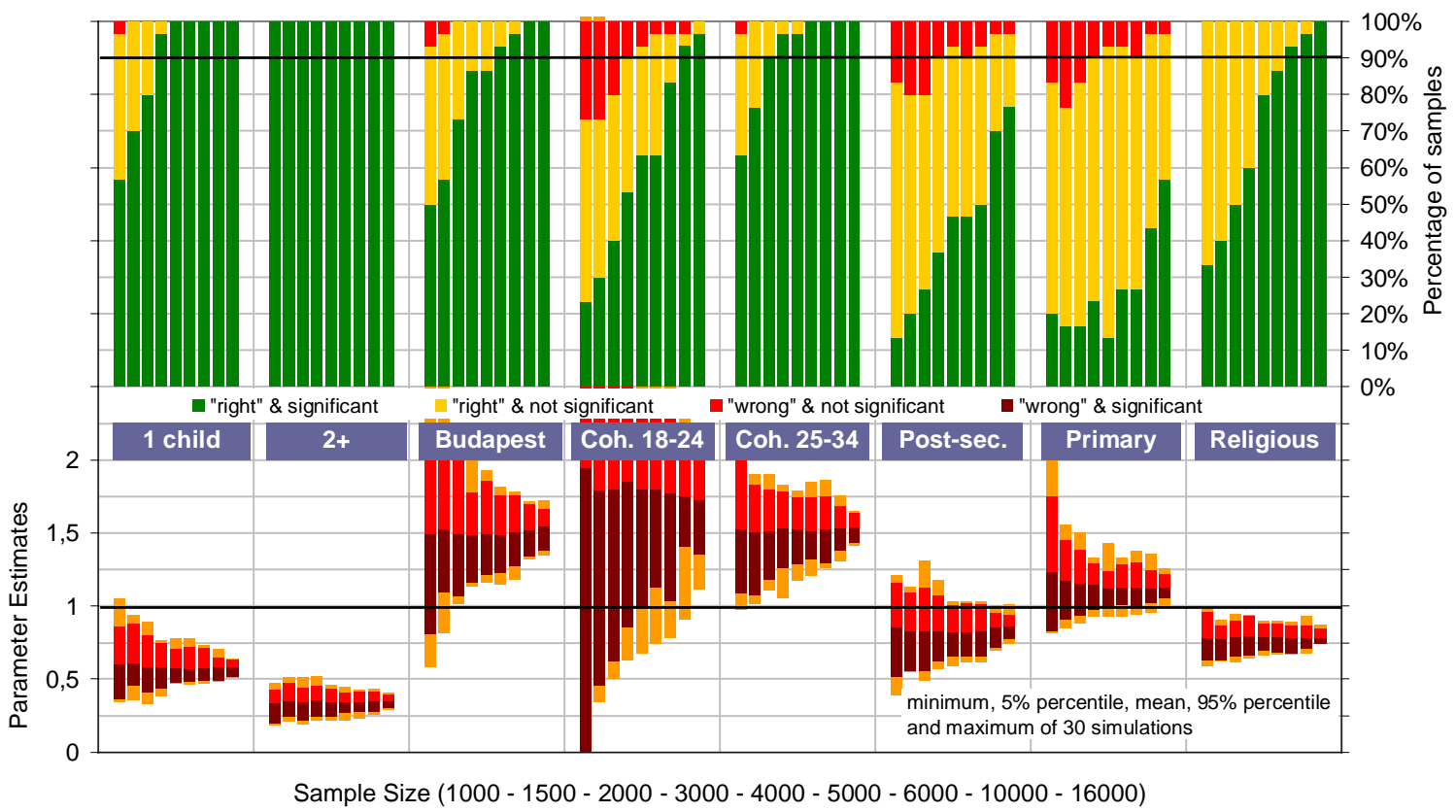

Figure 6: Relative risks of first divorce estimated from full biographies

An alternative way to study the marginal gains of an augmenting sample size in terms of an increasing probability to obtain significant parameter estimates is by counting the 
parameters of all four models that are significant in a given percentage of cases. Figure 7 displays the percentage of significant parameters using 6 alternative thresholds, namely for three significance levels $p=0,1$ (as above), $p=0,05$ and $p=0,01$ and the requirement to reach this significance in $90 \%$ of the samples (as above) and alternatively in all 30 of the simulated samples.

SIGNIFICANT PARAMETERS: PERCENTAGE OF ALL MODEL PARAMETERS OF 4 MODELS THAT ARE SIGNIFICANT AT DIFFERENT ALTERNATIVE LEVELS BY SAMPLE SIZE

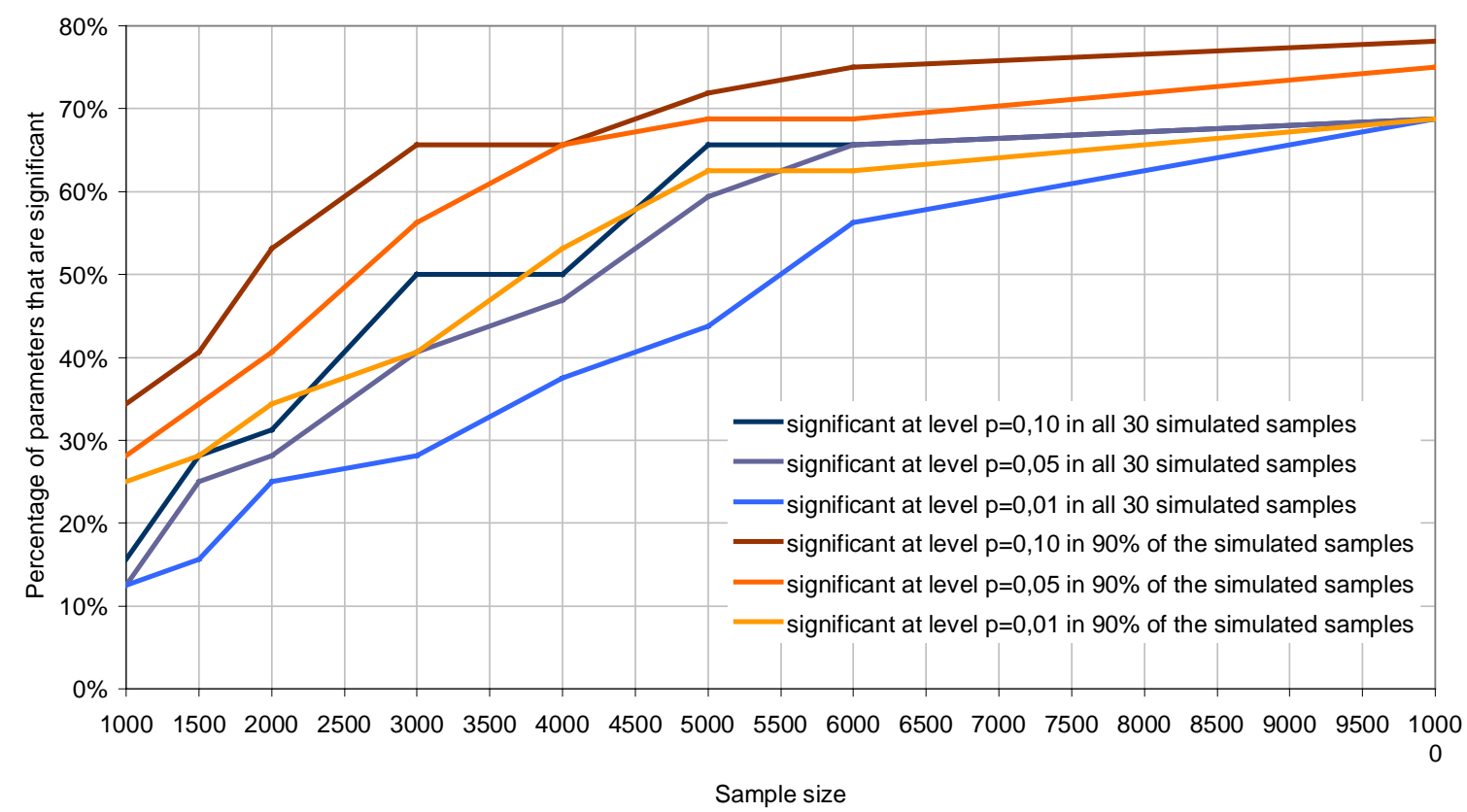

Figure 7: Sample size and number of parameters that become significant

For a significance level of $\mathrm{p}=0,1$, marginal gains are very high up to a sample size of 3.000. When increasing the aspired significance threshold, marginal gains are high and almost constant up to 6.000 respondents.

\section{Simulation results for a 3-year inter-panel interval}

When limiting the observation period to the last three years - a three-year panel-interval of the GGS - the likelihood of obtaining significant estimation results decreases considerably. Even though the risk of obtaining significant but "wrong" parameter estimates as defined above (i.e. greater than unity for under-proportional risks and less than unity for overproportional risks) stays below 5\% for almost all parameters and sample sizes, most estimates are "right" but not significant. Again, the probability to obtain significant parameter estimates is very sensitive to the sample size, especially in the sampling range of the GGS; but the probability that a parameter estimate is significant stays usually well below 50\%: For a sample size of 3.000 , only $30 \%$ of the parameters have at least a $50 / 50$ 
chance (an odd of one) to be significant. Only 2 out of the estimated 24 parameters are significant in $90 \%$ of the samples.

MARRIAGE: PARAMETER ESTIMATES FROM 30 SIMULATED SAMPLES FOR DIFFERENT SAMPLE SIZES AND PERCENTAGE OF SAMPLES IN WHICH PARAMETERS ARE SIGNIFICANT AT LEVEL 0,1 - 3 YEAR INTERVAL

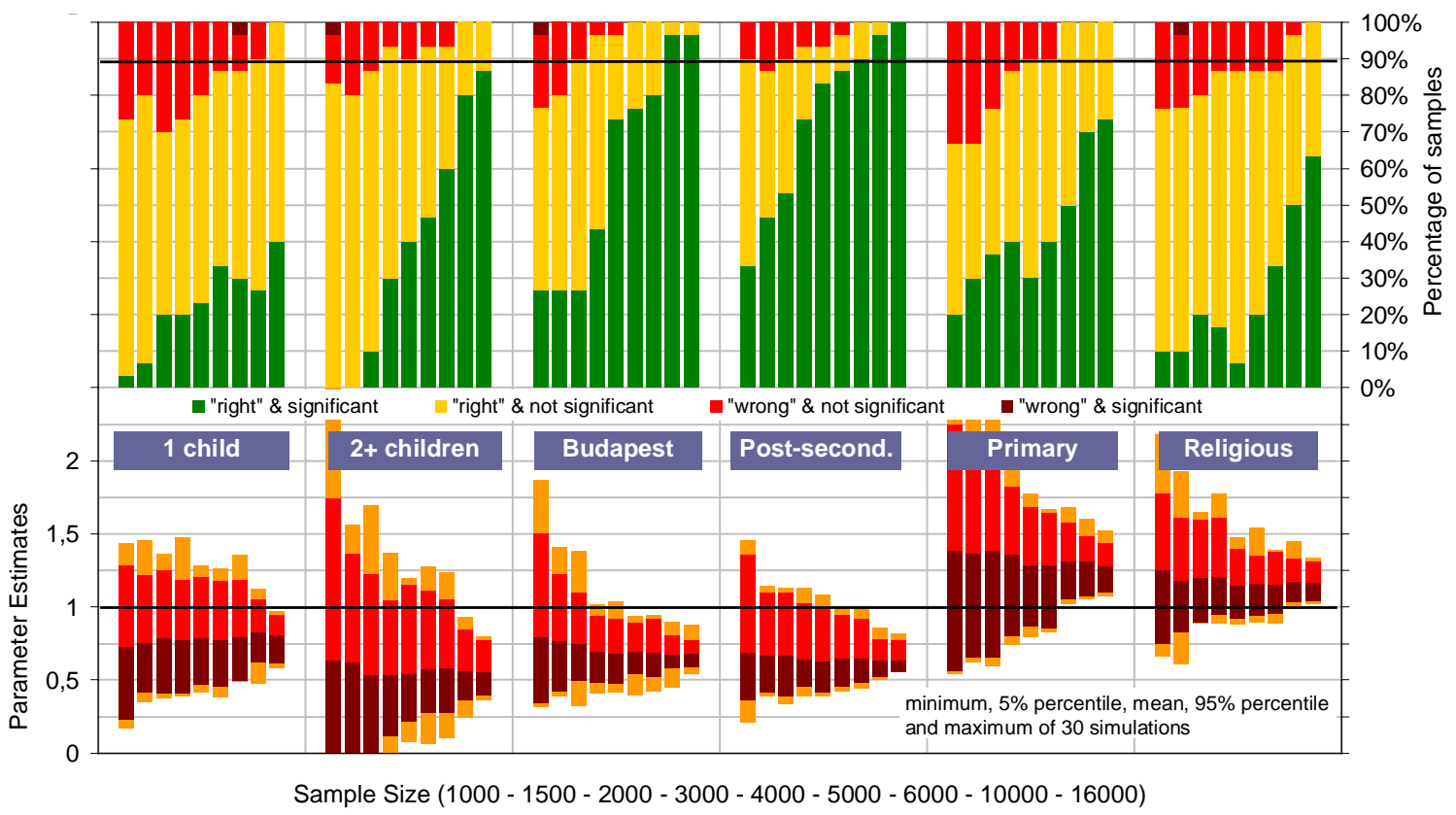

Figure 8: Relative risks of first marriage estimated from 3-year inter-panel biographies

FIRST BIRTH: PARAMETER ESTIMATES FROM 30 SIMULATED SAMPLES FOR DIFFERENT SAMPLE SIZES AND PERCENTAGE OF SAMPLES IN WHICH PARAMETERS ARE SIGNIFICANT AT LEVEL 0,1 - 3 YEAR INTERVAL

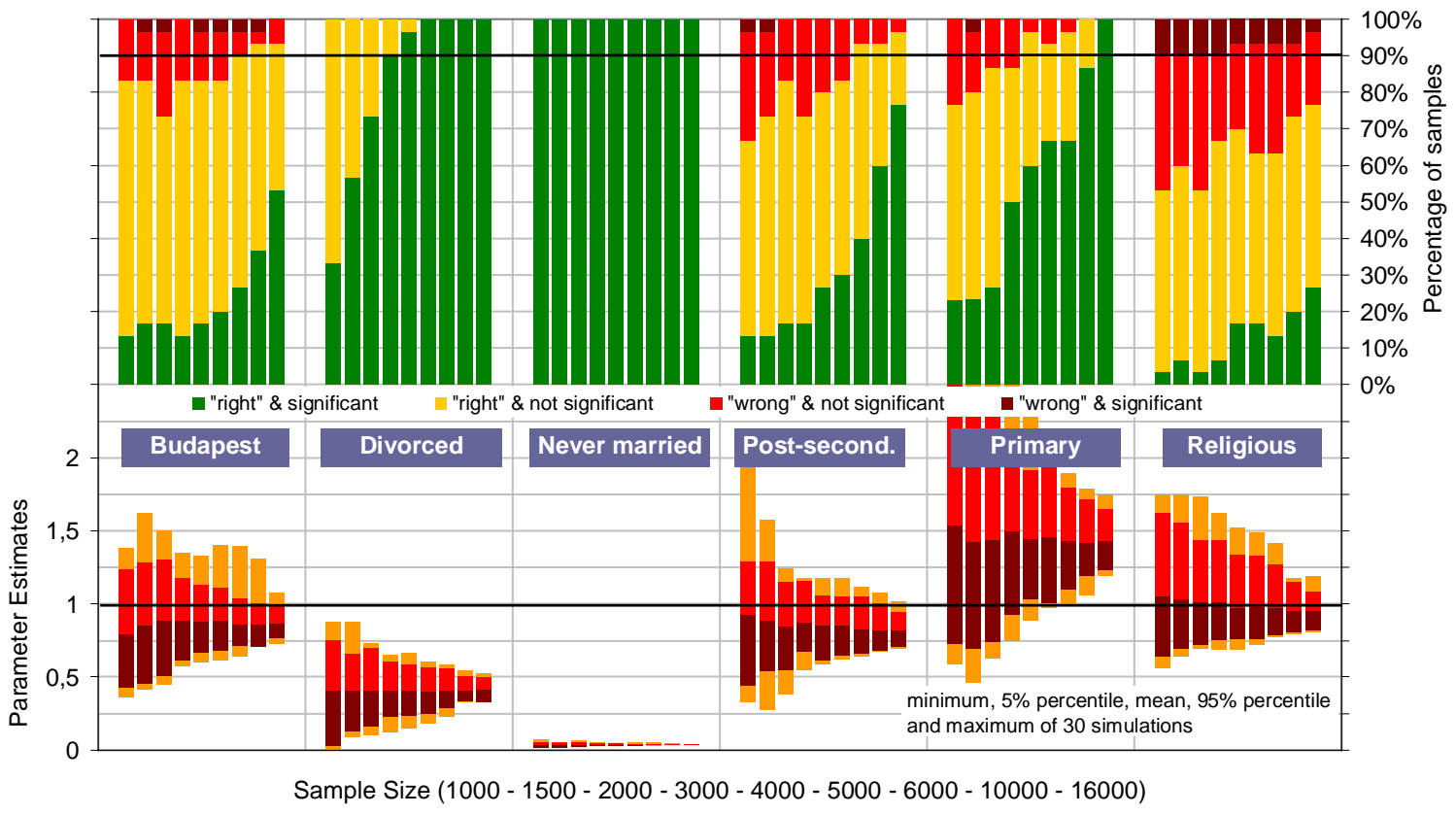

Figure 9: Relative risks of first birth estimated from 3-year inter-panel biographies 
SECOND BIRTH: PARAMETER ESTIMATES FROM 30 SIMULATED SAMPLES FOR DIFFERENT SAMPLE SIZES AND PERCENTAGE OF SAMPLES IN WHICH PARAMETERS ARE SIGNIFICANT AT LEVEL 0,1 - 3 YEAR INTERVAL

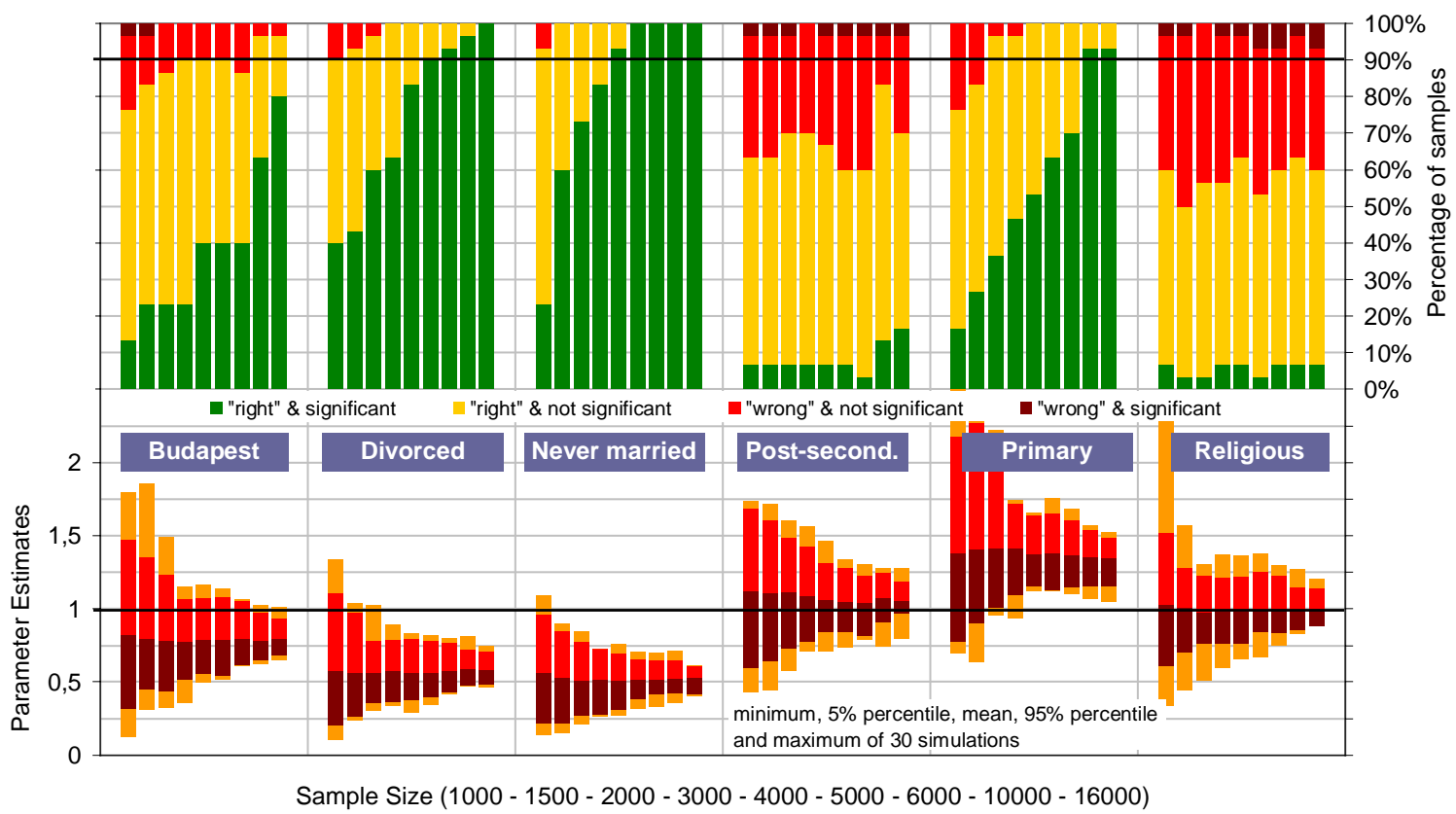

Figure 10: Relative risks of second birth estimated from 3-year inter-panel biographies

DIVORCE: PARAMETER ESTIMATES FROM 30 SIMULATED SAMPLES FOR DIFFERENT SAMPLE SIZES AND PERCENTAGE OF SAMPLES IN WHICH PARAMETERS ARE SIGNIFICANT AT LEVEL 0,1 - 3 YEAR INTERVAL

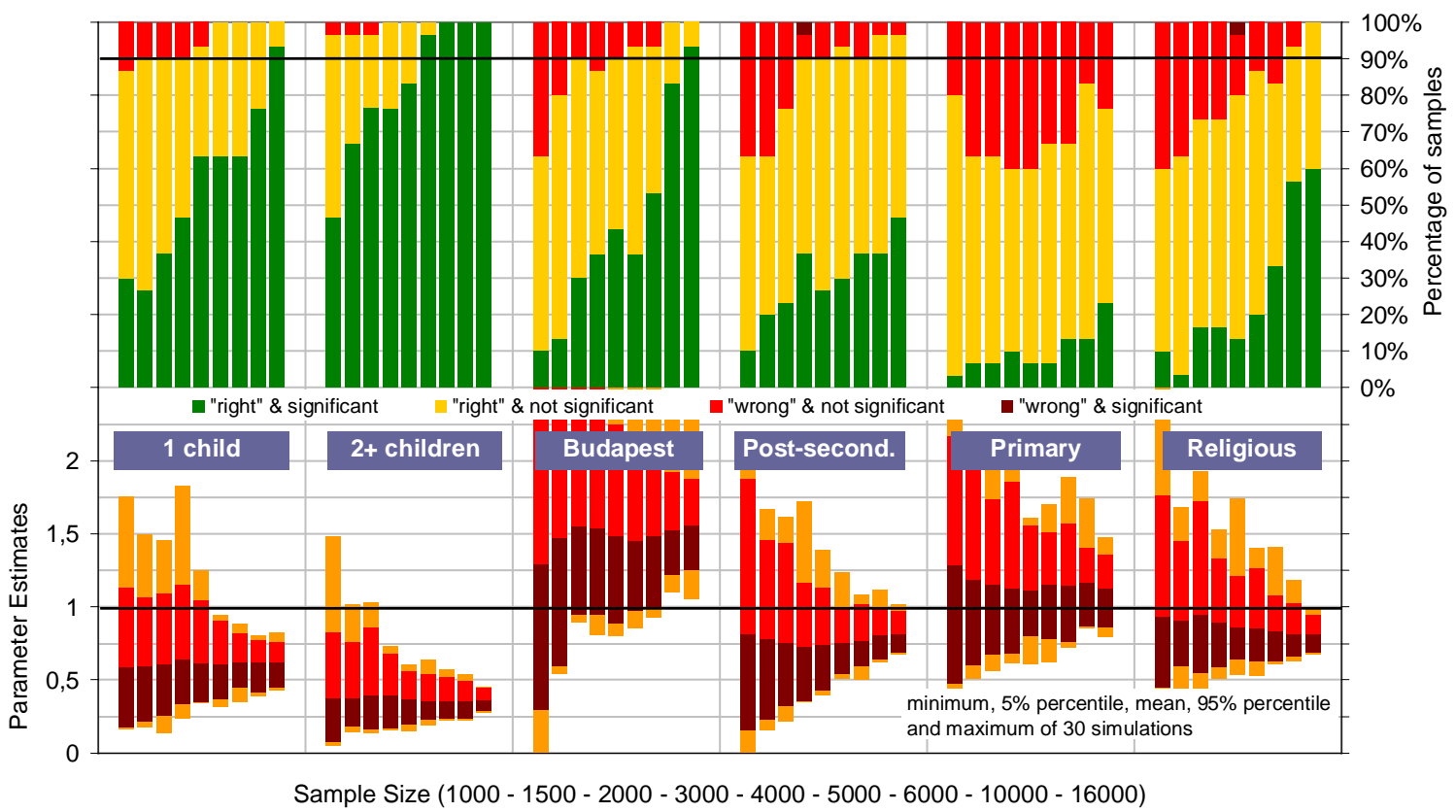

Figure 11: Relative risks of first divorce estimated from 3-year inter-panel biographies 


\section{Simulation results for a 6-year inter-panel interval}

When increasing the observation period to six years - two successive three-year panelintervals of the GGS - the likelihood of obtaining significant estimation results increases. While the risk of obtaining significant but "wrong" parameter estimates as defined above (i.e. greater than unity for under-proportional risks and less than unity for overproportional risks) almost disappears, most estimates have also a high likelihood of being significant. For a sample size of 3.000, almost half of the parameters have at least a 50/50 chance to be significant and one fourth of the estimated 24 parameters is significant in $90 \%$ of the samples.

MARRIAGE: PARAMETER ESTIMATES FROM 30 SIMULATED SAMPLES FOR DIFFERENT SAMPLE SIZES AND PERCENTAGE OF SAMPLES IN WHICH PARAMETERS ARE SIGNIFICANT AT LEVEL 0,1 - 6 YEAR INTERVAL

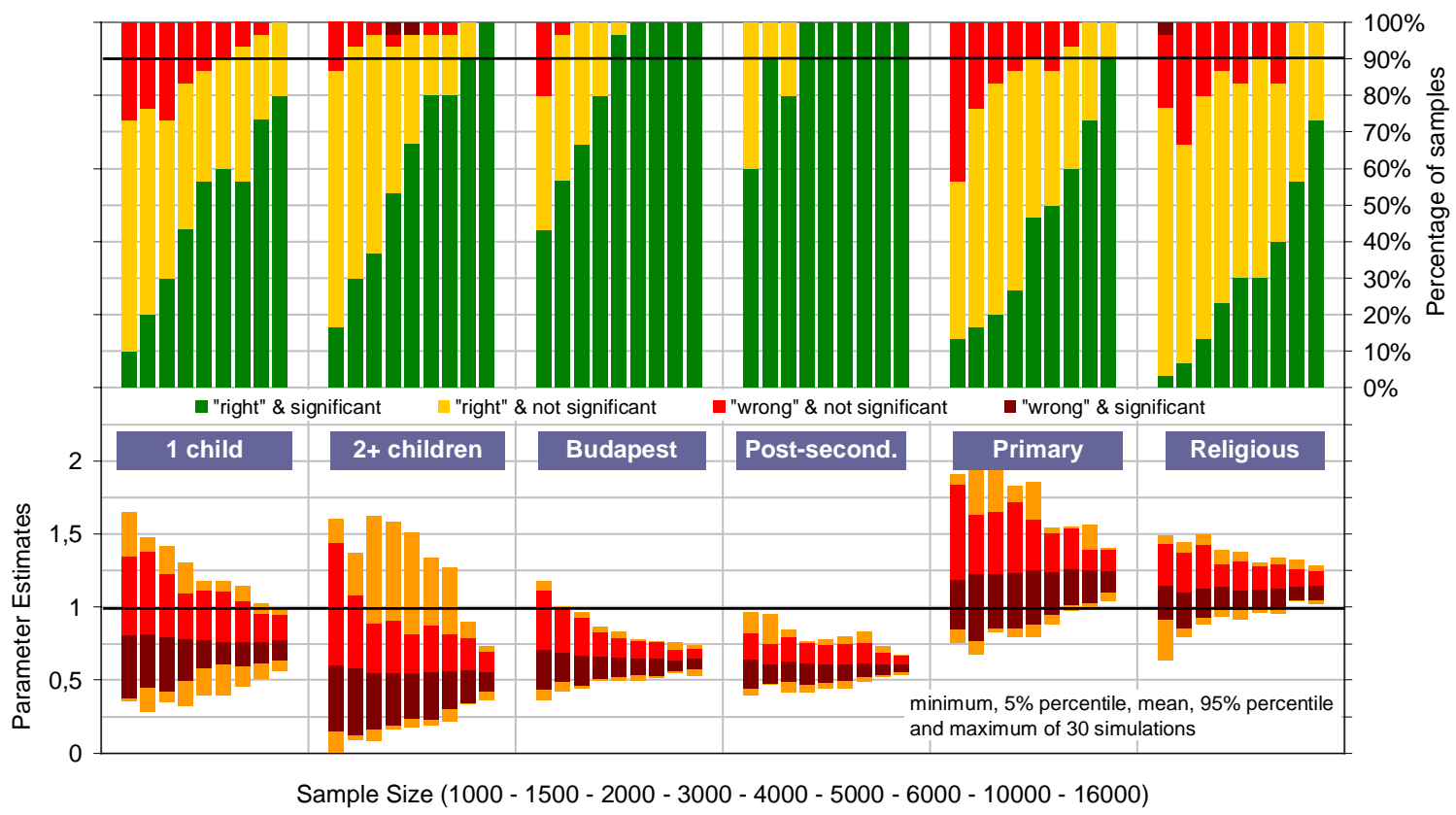

Figure 12: Relative risks of first marriage estimated from 6-year inter-panel biographies 
FIRST BIRTH: PARAMETER ESTIMATES FROM 30 SIMULATED SAMPLES FOR DIFFERENT SAMPLE SIZES AND PERCENTAGE OF SAMPLES IN WHICH PARAMETERS ARE SIGNIFICANT AT LEVEL 0,1 - 6 YEAR INTERVAL

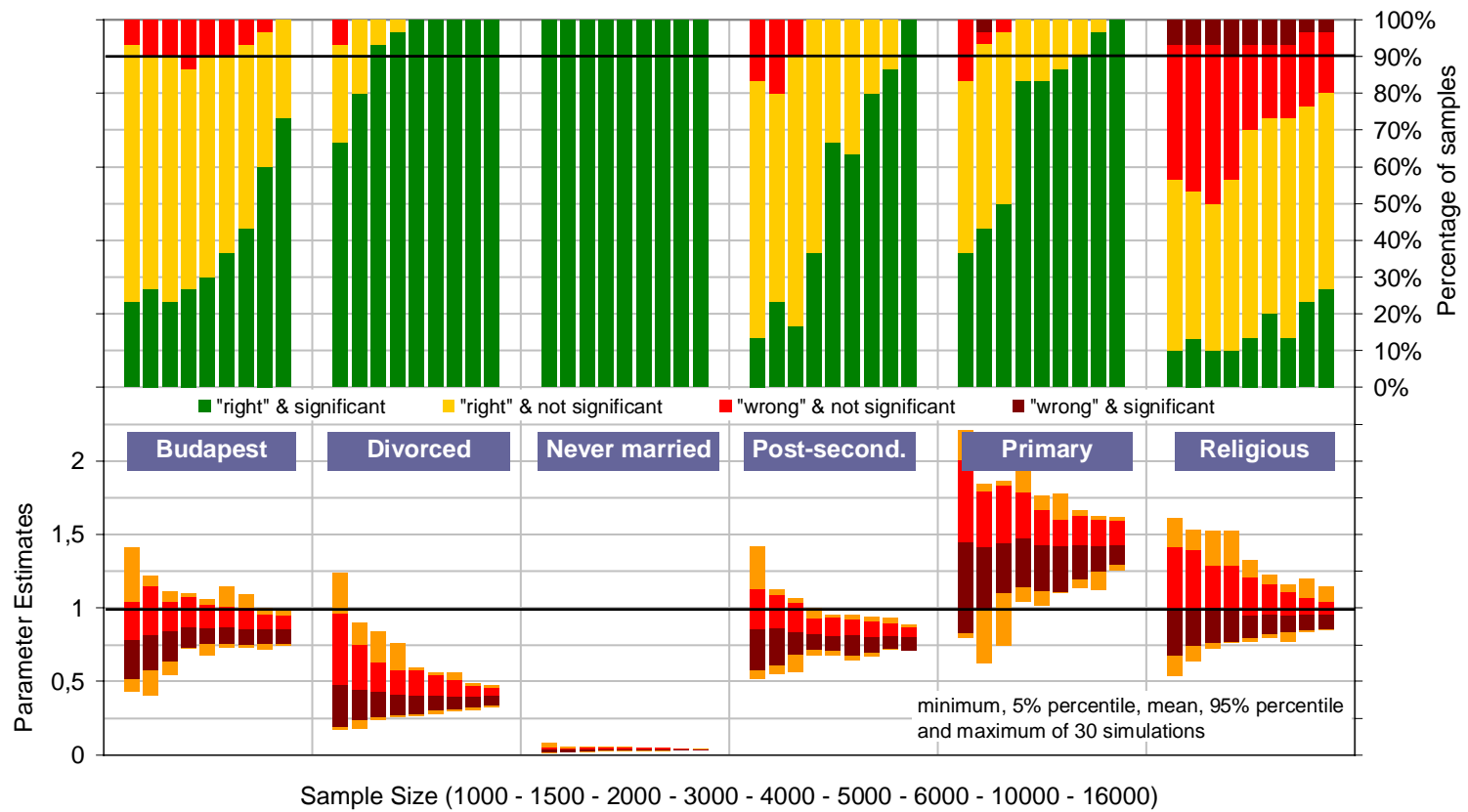

Figure 13: Relative risks of first birth estimated from 6-year inter-panel biographies

SECOND BIRTH: PARAMETER ESTIMATES FROM 30 SIMULATED SAMPLES FOR DIFFERENT SAMPLE SIZES AND PERCENTAGE OF SAMPLES IN WHICH PARAMETERS ARE SIGNIFICANT AT LEVEL 0,1 - 6 YEAR INTERVAL

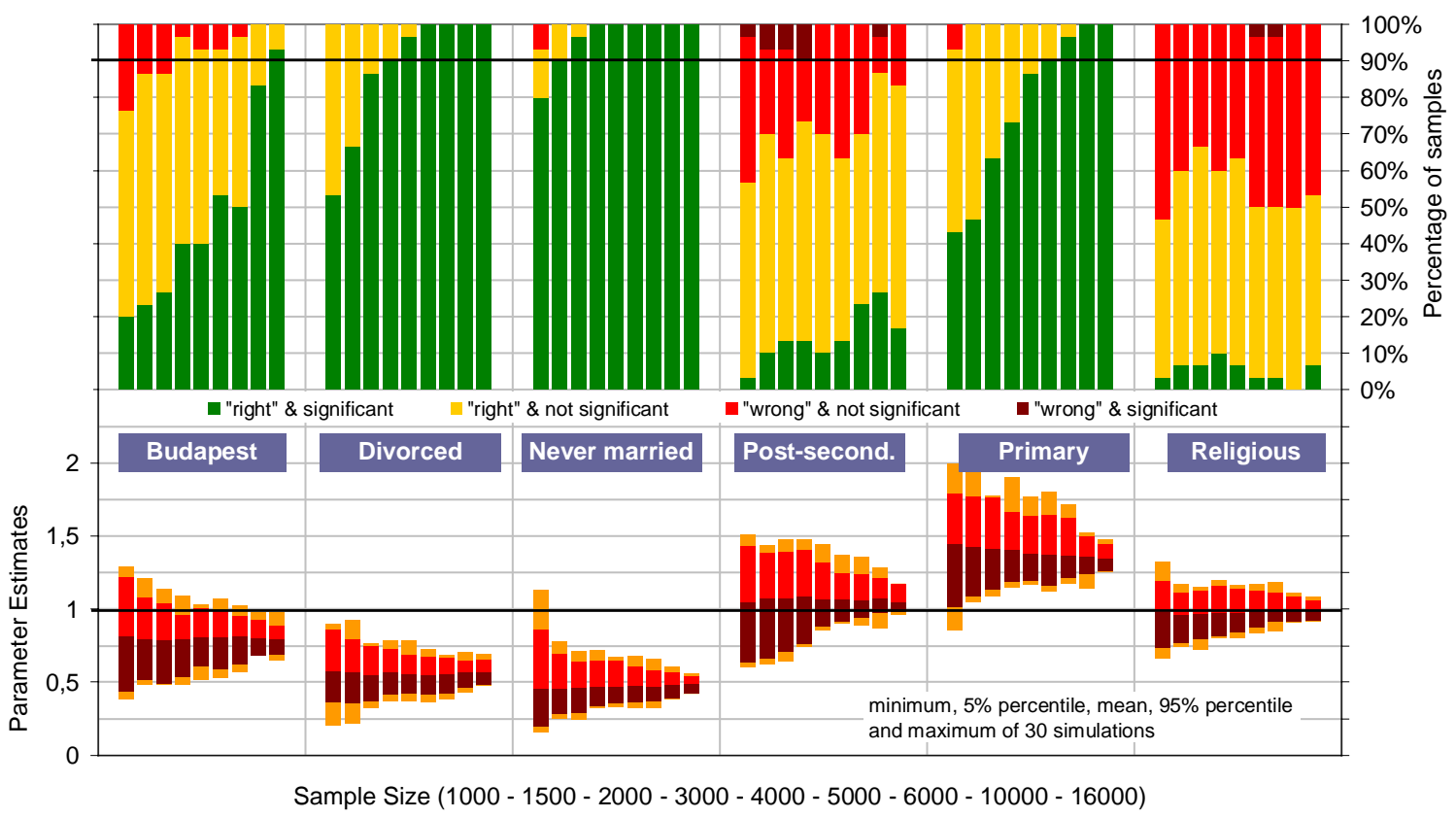

Figure 14: Relative risks of second birth estimated from 6-year inter-panel biographies 
DIVORCE: PARAMETER ESTIMATES FROM 30 SIMULATED SAMPLES FOR DIFFERENT SAMPLE SIZES AND PERCENTAGE OF SAMPLES IN WHICH PARAMETERS ARE SIGNIFICANT AT LEVEL 0,1 - 6 YEAR INTERVAL

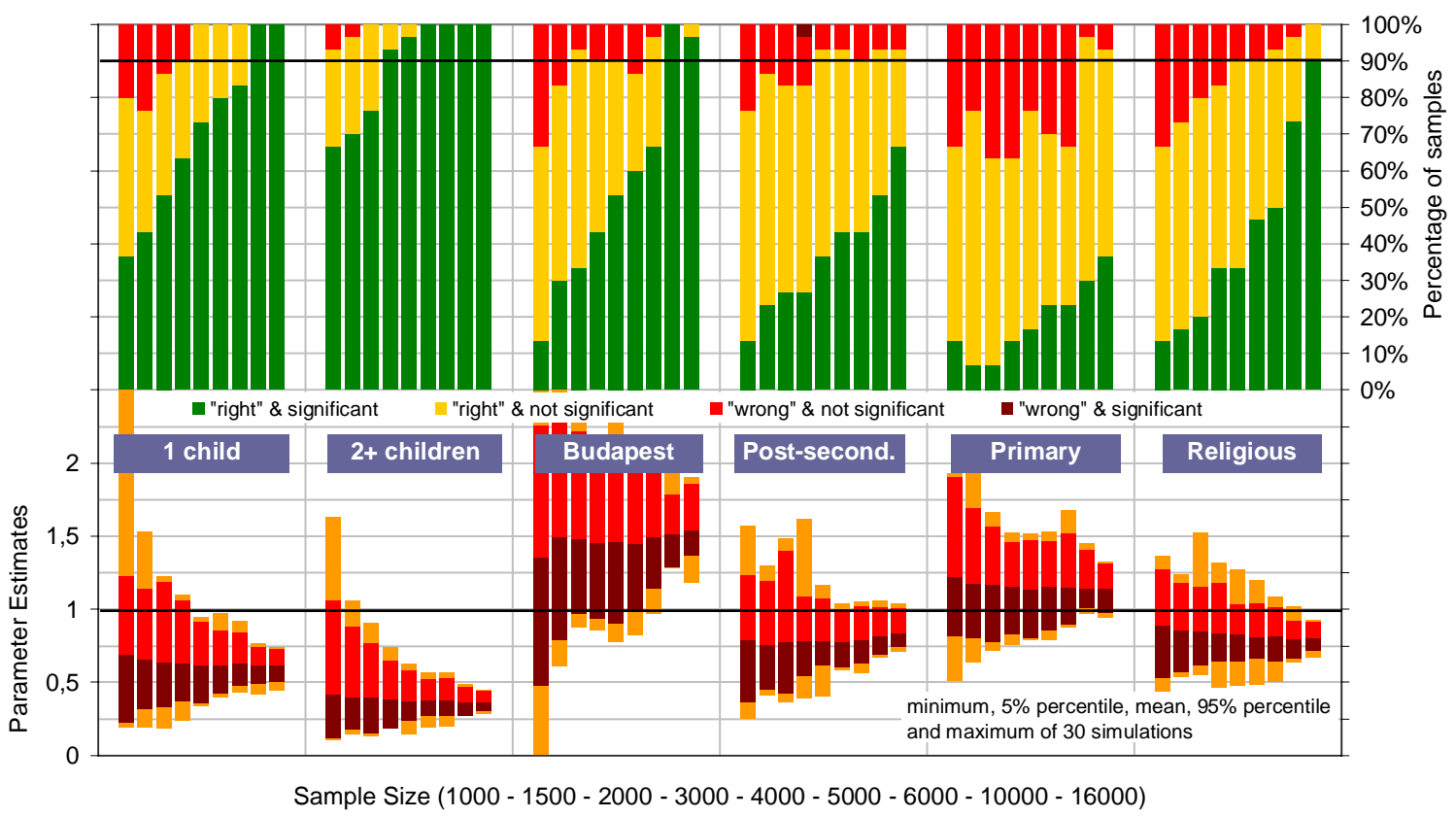

Figure 15: Relative risks of first divorce estimated from 6-year inter-panel biographies

\section{Comparison of results and conclusions}

The following graph compares the number of parameters that are significant in $90 \%$ of the simulated samples for the three studied observation periods. This probability steeply increases up to a sample size of 3.000 for the full observation period. We observe a steep increase for shorter observation periods when augmenting the sample size from 2.000 to 3.000 where the number of significant parameters doubles, followed by high and almost constant marginal gains up to sample sizes of 16.000 . 


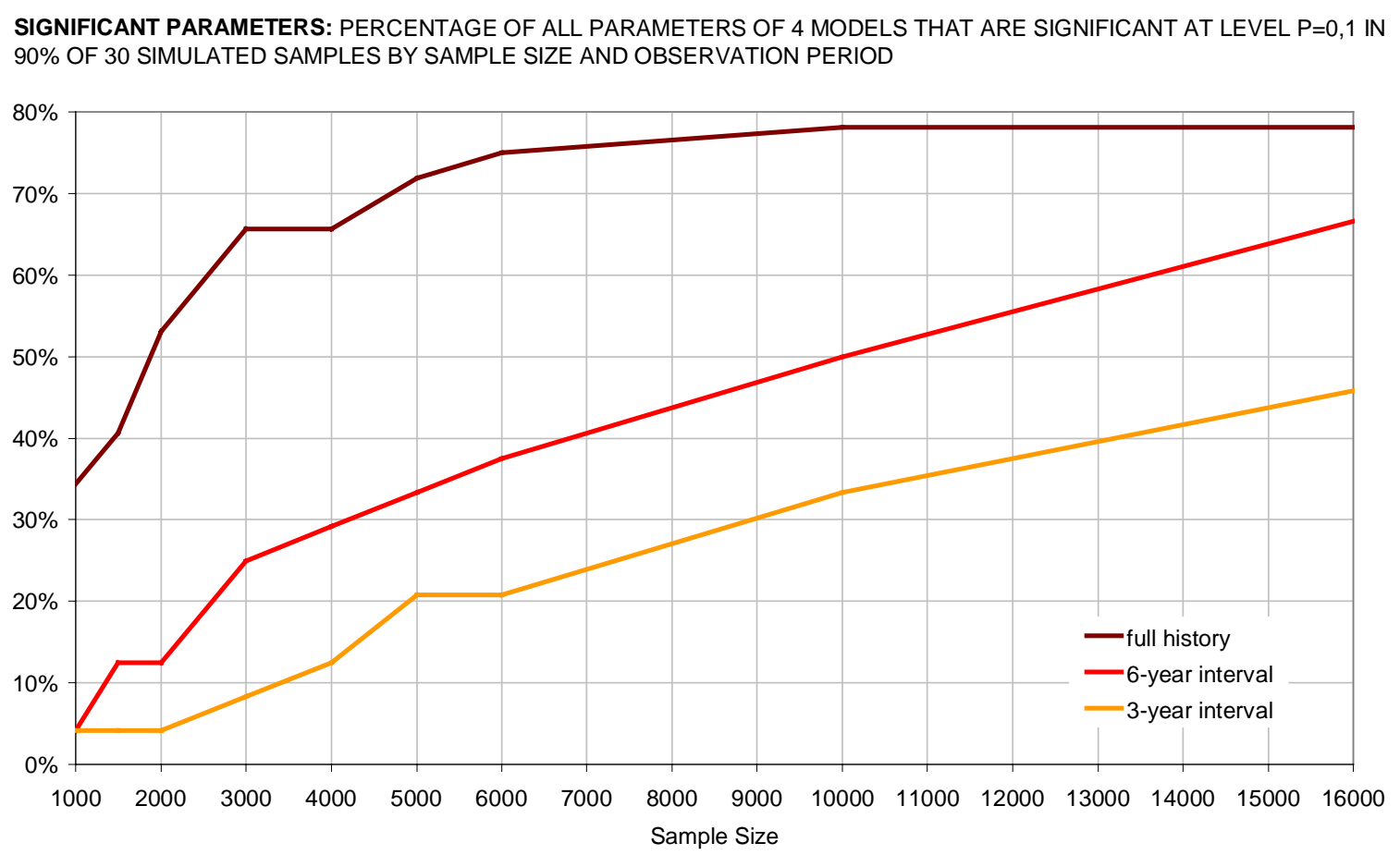

Figure 16: Percentage of model parameters that are significant at level $p=0,1$ in $90 \%$ of the simulated samples

In general, the simulation results indicate that there is great sensibility of the parameters that reach statistical significance to the sample size precisely in the sample range of the GGS. This means that any reduction or increase in the sample size will notably affect the statistical analysis of the data. Marginal gains in terms of the number of significant parameters are especially high up to 3.000 respondents when applying the rather modest threshold of significance of $\mathrm{p}=0,1$ in $90 \%$ of the simulated samples. For higher thresholds, marginal gains remain steep for sample sizes of up to 5.000 respondents. When analyzing inter-panel histories, especially for a single three-year interval, the likelihood that parameter estimates are significant is very moderate. When analyzing 6-year inter-panel histories, for a sample size of 3.000, almost half of the parameters have at least a 50/50 chance of being significant at level $\mathrm{p}=0,1$ and one fourth of the parameters estimates are significant in $90 \%$ of the samples. When reducing the sample size to below 3.000, the number of significant results for inter-panel histories deteriorates rapidly, e.g. by $50 \%$ with a reduction to 2.000 . 


\section{References}

Galler, H.P. (1997), Discrete-Time and Continuous-Time Approaches to Dynamic Microsimulation Reconsidered. Technical Paper 13. National Centre for Social and Economic Modeling (NATSEM), University of Canberra.

Imhoff, E.V. and Post, W. (1998), Microsimulation Methods for Population Projection. New Methodological in the Social Sciences, pp. 97-138.

Klevmarken, N.A. (1997), Behavioral Modeling in Micro Simulation Models. A Survey. Working Paper 1997:31, Department of Economics, Uppsala University.

Merz, J. (1991), Microsimulation - a survey of principles, developments and applications, International Journal of Forecasting, Vol. 7, No. 1.

Spéder, Z. (2001), Turning Points of the Life-course, Research Plan and Questionnaire of the Hungarian Social and Demographic Panel Survey (HSDPS), Draft, Budapest, Hungarian Central Statistical Office, Demographic Research Institute.

Spielauer, M. (2003), A Socio-Demographic Microsimulation Model for Austria: General Framework and Application for Educational Projections - Doctoral Thesis at the University of Vienna, 2003 